\title{
Translating Masculinity Into Different Culture: Is Jacob Black Masculine in Indonesian Version of Twilight Saga Novels?
}

\author{
Yopi Thahara $^{1 *}$, Riyadi Santosa ${ }^{2}$, M.R. Nababan ${ }^{3}$, and Dyah Ayu Nila Khrisna ${ }^{4}$ \\ ${ }^{1234}$ Linguistic Study Program, Faculty of Cultural Science, Universitas Sebelas Maret, Surakarta, Indonesia \\ *Corresponding author. E-mail: yopi.thahara87@student.uns.ac.id
}

\begin{abstract}
The realization of masculinity can be in the form of expressions uttered by characters in the novel. This research is aimed to examine the translation of expressions containing Jacob Black's masculinity in the Stephanie Meyer's Twilight Saga Novels and its Indonesian translation. This translation research uses Systemic Linguistic Functional especially Appraisal theory as a tool in the investigation. Qualitative research is used. Data are taken from four series of Twilight novel with purposive sampling. Data are analyzed by determining the masculinity in the novels of Twilight Saga and its Indonesian translations, determining the appraisal system of the source text and target text and comparing both systems to evaluate the translation of masculinity expressions. The result shows that (1) Jacob Black's masculinities are in the form of physical, interpersonal, intellectual, sexual, and emotional; (2) The change of appraisal systems will affect the messages (masculinity) in the target text; (3) Masculinity in the target text are mostly maintained (4) There are 13 translation techniques used to translate Jacob Black' Masculinity expressions in which established equivalence is dominantly used. This research could be the consideration in translating men's character into Indonesian and other languages.
\end{abstract}

Keywords: Masculinity, Appraisal System, Translation, Translation Technique

\section{INTRODUCTION}

The appearances of Jacob Black character in the novel Twilight Saga have raised the heat of the story. In the novel twilight saga, Jacob is a character that is emerged by the author in the middle of the story. In the story, Jacob is also falling in love to Bella who has already had a close friend, Edward, so that Bella confuse to choose between two. Jacob is depicted as a masculine man with perfect body, smart, brave, etc. In this research, Jacob's masculinity utterances in the novel twilight saga is interested

Research about masculinity has been done by several researches by using different kinds of theories. They are Chan [1], Rieser [2], Fouz-Hernández [3], Boyle and Brayton [4], Forth [5], Moran [6], Gordon [7], Lea and Schoene [8], Piera [9], and Gallagher [10].

\subsection{Masculinity}

Masculinity in this research is focused on the theory of Chafetz about masculinity. This theory is traditional masculinity, but it can holistically describe a character in the novel. There are 7 traits of masculinity proposed by Chafetz. They are physical, functional, sexual, emotional, intellectual, interpersonal, and other personal [11]. Physical means that masculinity is assessed by physical appearances, such as virile, athletic, strong, etc. Functional is masculinity traits that shows man is breadwinner and as a provider to woman. Sexual is realized by aggressiveness. Emotional means that man is unemotional, stoic and don't cry in any situation. Intellectual is traits that shows man is logical, intellectual, rational, objective, practical, mechanical, public awareness, and dogmatic. Interpersonal is masculinity man that can be a leader, dominating, discipline, independent, free, individualistic, and demanding. Other personal is aggressive, success oriented, ambitious, proud, egotistical, confident, moral, trustworthy, decisive, competitive, adventurous, and competitive. In this research, those traits are used to find the linguistics evidences that show Jacob masculinity.

\subsection{Appraisal}

Appraisal is theory appraisal in this research is used to analyze the attitude of the utterances. Martin and White's [12] theory of appraisal is used. The theory appraisal in this research covers attitude and engagement. Attitudes are divided into three; judgment, appreciation, and affect Judgment is used to evaluate behavior. Appreciation is attitude that assesses an aesthetic and evaluates text/process, natural 
phenomenon. Affect is attitude that shows someone emotion. Affect is reacting to behavior, text/process, and phenomena. Engagement deals with the source of attitude. The source of attitude

\subsection{Translation Techniques}

Translation techniques used in this research are proposed by Molina and Albir [13]. They proposed 18 translation techniques; they are adaptation, amplification, borrowing, calque, compensation, description, discursive creation, established equivalence, generalization, linguistic amplification, literal translation, linguistic compression, modulation, particularization, reduction, substitution, transposition, variation. Translation techniques are used to analyze Jacob masculinity utterances because translation techniques deal with micro scope of translation. The utterances of masculinity in this research are in the form of words, phrases or clauses. Hence, translation techniques are appropriate to investigate the translation of masculinity utterances.

\section{METHODS}

This research is descriptive qualitative research that describes translation of Jacob masculinity utterances in the novel Twilight Saga. The utterances are taken from 4 novel of Twilight Saga. The utterances consisted other characters' attitudes toward Jacob's masculinity are analyzed. The masculinity utterances are classified based on Chafetz's theory and analyzed using appraisal theory. The translation techniques used to translate the masculinity is also analyzed. The steps of analysis are domain, taxonomy, componential, and finding cultural values [14]. In the domain analysis, Jacob masculinity utterances are collected and selected based on the theory. The masculinity utterances are classified based on its' characteristics. In this step, the attitudes in the utterances are analyzed using appraisal theory and the translation techniques used to translate the utterances are analyzed. Componential analysis is connecting the variables of kinds of masculinity utterances, appraisal system, and translation techniques to find out the patterns of the data. In this analysis, the researcher analyzes the preferences that emerge in the data analysis. Finding cultural values is describing the preferences found in the componential analysis by relating them with the theories related to the research and previous studies.

\section{RESULTS}

\subsection{Jacob' Masculinity}

The utterances that show Jacob Black's masculinities are the realization from the work of Chafetz in the masculinity. The results of Jacob masculinity utterances in the source language discourse (SL) and target language (TL) discourse are listed in the table 1 .

Table 1. Jacob's masculinity

\begin{tabular}{|l|c|c|}
\hline Kinds of masculinity & SL & TL \\
\hline Physical appearance & $60(58,82 \%)$ & $60(58,82 \%)$ \\
\hline Interpersonal & $18(17,64 \%)$ & $18(17,64 \%)$ \\
\hline Intellectual & $12(11,76 \%)$ & $12(11,76 \%)$ \\
\hline Sexual & $11(10,78 \%)$ & $11(10,78 \%)$ \\
\hline Emotional & $1(0,98 \%)$ & $1(0,98 \%)$ \\
\hline Total & 102 & 102 \\
\hline
\end{tabular}

There are five kinds of masculinity utterances in the data; physical, interpersonal, intellectual, sexual, and emotional. Jacob Black's masculinity is dominantly described in the physical appearances with 58,82\%. Jacob Masculinity is depicted in the interpersonal with $17,64 \%$ data. The other characteristics of Jacob's masculinities are intellectual $(11,76 \%)$, sexual $(10,78 \%)$, and Emotional $(0,98 \%)$.

\subsection{Appraisal System}

The realizations of appraisal system in the Jacob's masculinity utterances analyzed are in the form of attitude and engagement.

\subsubsection{Attitude}

Attitude deals with evaluating things, people's character and their feeling [15]. Attitudes are classified based on the kinds of Jacob's masculinity utterances.

\subsubsection{Attitude of Physical Appearance}

Masculinity in the form of physical can be appraising his face, smile, body, etc. The attitudes in the physical masculinity in this research are in the form of affect and judgment. The attitude in the source language and target language can be seen in the following diagram:

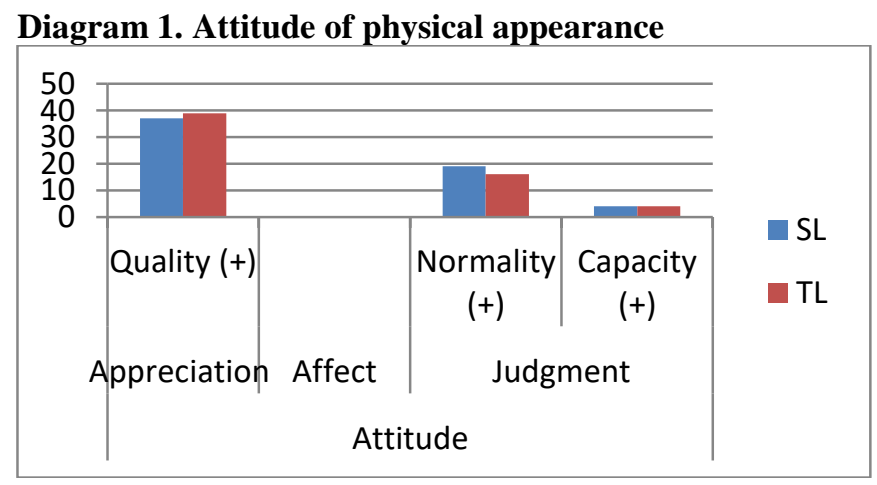


The attitudes in the physical masculinity are in the form of appreciation and judgment. SL attitudes are in the form of appreciation: quality (+) with 37 data and judgment with 23 data. Judgment is in the form of normality (+) with 19 data and capacity (+) with 4 data. TL attitudes consist of appreciation: quality (+) with 39 data, judgment: normality (+) with 16 data, and judgment: capacity $(+)$ with 4 data. The data show that there are some attitude data shifted in the target language. Jacob's physical appearances masculinity can be seen in the following example:

SL : He'd passed that point where the soft muscles of childhood hardened into solid, lanky build of a teenager

TL : Ia melewati titik di mana otot-otot masa kanakkanaknya mengeras membentuk sosok remaja bertubuh padat dan tegap.

The appraising item of the example is soft muscles of childhood hardened into solid, lanky build of a teenager and it is translated into otot-otot masa kanakkanaknya mengeras membentuk sosok remaja bertubuh padat dan tegap. In this case, Jacob's masculinity is described through his physical appearance by mentioning muscle. The attitude in the source language shows appreciation to his physical appearance, it is included into quality $(+)$. In the target language, the attitude is not changed.

\subsubsection{Attitude of Interpersonal}

Interpersonal is depicted as a man that is dominating, demanding, discipline, individualistic, independent, free, etc. The result shows that there are 18 data in interpersonal. The attitudes consist of 17 judgment and 1 appreciation data. There are 3 kinds of judgment appear in the interpersonal data; capacity $(+)$ with 2 data, tenacity (+) with 12 , and propriety (+) with 3 data. Only one data show the attitude of interpersonal. The attitude is appreciation: quality (+).

\section{Diagram 2. Attitude of Interpersonal}

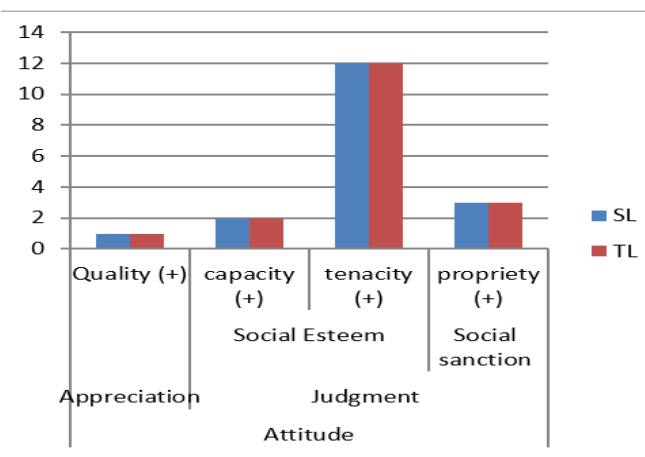

The realization of attitude of interpersonal is in the following example.

SL: He opened the front door and held it for me.

TL: Ia membukakan pintu depan dan memeganginya untukku.

Appraising item of this example is opened the front door and held it for me which is translated into membukakan pintu depan dan memeganginya untukku. The appraisal system is not changed.

\subsubsection{Attitude of Intellectual}

The attitudes that show Jacob's intellectual are 12 data. All data are included into judgment: social esteem: capacity (+) and they are not changed in the target language. Here is the example of Jacob's masculinity, especially in intellectual.

SL : ... but Jacob seemed to consider the speed restrictions a shortcoming.

TL.: ... tapi Jacob sepertinya menganggap batas kecepatan truk ini sebagai kekurangan.

In the example, the appraising item is seemed to consider the speed restrictions a shortcoming. It is translated into sepertinya menganggap batas kecepatan truk ini sebagai kekurangan. Jacob's intellectual masculinity is manifested in his expertise in driving truck in which he can easily drive his truck in high speed. It is translated into the same kind of masculinity in target language.

\subsubsection{Attitude of Sexual}

Sexual is one of Jacob's masculinity that is depicted in the novel Twilight Saga. There are 11 data included into sexual masculinity. All data in the attitude of sexual are categorized as affect: happiness: affection. Here is the example of Jacob's sexual masculinity:

SL : He reached out and took my hand firmly, wrapping his other hand around my wrist...

TL : Ia mengulurkan tangan dan dengan mantap meraih tanganku, menarik pinggangku,

The appraising item in this example is reached out and took my hand firmly, wrapping his other hand around my wrist which is translated into mengulurkan tangan dan dengan mantap meraih tanganku, menarik pinggangku. In this case, Jacob shows his aggressiveness to Bella. 


\subsubsection{Attitude of Emotional}

Emotional masculinity is described as a man that is unemotional, stoic, and "don't cry". In this research, there is only one data that shows Jacob unemotional. His masculinity is contained in this example.

\section{SL : Jacob's face was a calm mask ...}

TL : Wajah Jacob berupa topeng tenang...

Appraising attitude is a calm mask which is translated into berupa topeng tenang. A calm mask means that Jacob is unemotional when he faces a problem. The narrator assesses that he is masculine because he can control his emotion. The attitude of this expression is judgment: capacity (+).

\subsubsection{Engagement}

The sources of attitude in this research are coming from all characters in the novel. The sources of attitude are divided into two, heterogloss and monogloss. This is the diagram of the engagement.

\section{Diagram 3. Engagement}

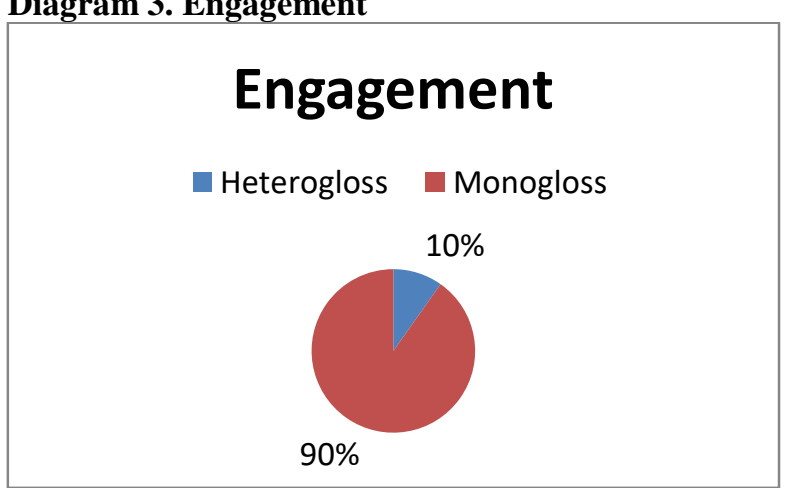

The diagram shows that monogloss is the dominant source of attitude. Monogloss consists of 92 data, meanwhile heterogloss appears in 10 data. Monogloss in this research is coming from the narrator and heterogloss is coming from other characters in the novel. The narrator in this novel is Bella.

\subsection{Translation Techniques}

The translation techniques used to translate Jacob's masculinity utterances are established equivalence, variation, explicitation, modulation, paraphrase, natural borrowing, discursive creation, compensation, transposition, implicitation, adaptation, reduction, and literal. Table shows the frequency of translation technique used.
Table 2. Translation Techniques

\begin{tabular}{|r|l|c|}
\hline No & Translation Technique & Frequency \\
\hline 1 & Established Equivalence & 208 \\
\hline 2 & Variation & 16 \\
\hline 3 & Explicitation & 15 \\
\hline 4 & Modulation & 10 \\
\hline 5 & Paraphrase & 8 \\
\hline 6 & Natural Borrowing & 7 \\
\hline 7 & Discursive Creation & 4 \\
\hline 8 & Compensation & 4 \\
\hline 9 & Transposition & 3 \\
\hline 10 & Implicitation & 2 \\
\hline 11 & Adaptation & 2 \\
\hline 12 & Reduction & 1 \\
\hline 13 & Literal & 1 \\
\hline & Total & 281 \\
\hline
\end{tabular}

Based on the data, Established equivalence is the dominant translation technique used to translate Jacob's masculinity utterances. Established equivalence technique is dominantly used because the technique doesn't change the appraisal system in the target language. Meanwhile, some techniques change the appraisal system in the target language; such as reduction and discursive creation. The change of appraisal system can cause the sense of masculinity changing.

\section{DISCUSSION OF RESULTS}

Jacob masculinities in this research are realized in the form of physical appearances, interpersonal, intellectual, sexual, and emotional. Physical appearances dominantly describe Jacob masculinity. Jacob are described that he has a good shape of body, he has manly voice, and etc. In addition, Jacob is also described as a man with high intelligent that It means that the traditional theory of masculinity proposed by Chafetz is able to describe the phenomena of Jacob Black's masculinity in the novel Twilight saga.

Jacob masculinity utterances in this research are dominantly the realization of physical appearances. The utterances are dominantly coming from the narrator. The attitudes are dominantly in the form of judgment. Appreciation deals with Jacob appearances. Meanwhile, affect deals with Jacob affection during treating Bella (Narrator). If appraisal system in the source language and target language has the same system, it means that 
the message of masculinity is well translated in the target language.

The translation techniques are used to identify the micro unit of translation. Established equivalence is the dominant translation technique used to translate masculinity utterances. According to Molina \& Albir [13], established equivalence is carried out by using familiar expression in the target language. Hence, established equivalence can transfer Jacob masculinity well. Reduction and discursive creation techniques are potentially change the masculinity of Jacob Black in the target language.

\section{CONCLUSION}

Masculinities of Jacob Black in the Twilight Saga novel are in the form of physical appearances, interpersonal, intellectual, sexual, and emotional. The traditional theory of masculinity can describe the masculinity. The realizations of masculinity can be in the utterances containing attitudes. The change of attitude in the target language can change the message of masculinity in the source language. It means that masculinity utterances are not successfully translated into target language. There are 13 translation techniques used to translate Jacob Black's Masculinity expressions in which established equivalence is dominantly used.

\section{REFERENCES}

[1] J.W. Chan, "Bruce Lee's Fictional Models of Masculinity," Men and Masculinities, vol. 2, issue 4, pp. 371-381, Apr 2000.

[2] K. Rieser, "Masculinity and Monstrosity: Characterization and Identification in The Slasher Film," Men and Masculinities, vol. 3, issue 4, pp. 370-392, Apr 2001.

[3] S. Fouz-Hernández, "Phallic Matters? Ewan McGregor and the Representation of the Male Body in Peter Greenaway's The Pillow Book (1996)," Men and Masculinities, vol. 8, issue 2, pp. 133-147, Oct 2005.

[4] E. Boyle \& S. Brayton, "Ageing Masculinities and "muscle work" in Hollywood action film: An analysis of The Expendables," Men and Masculinities, vol. 15, issue 5, pp. 468-485, Nov 2012.

[5] C.E. Forth, "“Nobody Loves a Fat Man” Masculinity and Food in Film Noir," Men and Masculinities, vol. 16, issue 4, pp. 387-406, Sept 2013.

[6] L.S. Moran, L. S, "Men in mourning: depictions of masculinity in young and older widowers in contemporary film," Men and Masculinities, vol. 19, issue 1, pp. 85-104, June 2015.
[7] N. Gordon, "White masculinity and civility in contemporary Canadian short stories: The fantasy of reterritorialization and return," Men and Masculinities, vol. 17, issue 2, pp. 173-194, May 2014.

[8] D. Lea\& B. Schoene, "Introduction to the special section on literary masculinities," Men and Masculinities, vol. 4, issue 4, pp. 319-321, Apr 2002.

[9] M. Piera, "Performing Knighthood: The Hero Tirant lo Blanc in Drag," Men and Masculinities, vol. 15 issue 4, pp. 346-366, Sept 2012.

[10] M. Gallagher, "Masculinity in translation: Jackie Chan's transcultural star text," in Masculinity in Translation, The Velvet Light Traps, Ed. Texas: Univ. of Texas Press, 1997 pp. 23-39.

[11] J.S. Chafetz, Masculine/Feminine or Human? An Overview of the Sociology of Sex Roles, Itasca: FE Peacock Publishers, 1974.

[12] J.R. Martin, P.R. White, The language of evaluation, $2^{\text {nd }}$ ed, Basingstoke: Palgrave Macmillan, 2005.

[13] L. Molina, A. H. Albir, "Translation Technique and Revisited: A Dynamic and Functionalist Approach," Meta, Journal des Traducteur/Meta: Translators, vol. 47, pp. 498-512, Dec 2002.

[14] R. Santosa, Metode Penelitian Kualitatif Kebahasaan, Surakarta: UNS Press, 2017.

[15] J.R. Martin, D. Rose, Working With Discourse, London: Continuum, 2003. 